\title{
Katılımcı Yönetimde Önemli Bir Kavram Olarak Örgütsel Demokrasiye İlişkin; Ulusal Tez Merkezi, TR Dizin ve Dergipark Veri Tabanları Kapsamında Bir İçerik Analizi ${ }^{1}$
}

\author{
Emine Vasfiye KORKMAZ \\ Dr. Öğr. Üyesi, İskenderun Teknik Üniversitesi, \\ İşletme ve Yönetim Bilimleri Fakültesi, Ekonomi Bölümü \\ emine.korkmaz@iste.edu.tr \\ Orcid ID: https://orcid.org/0000-0001-7202-6849

\section{Adnan ÇELİK} \\ Prof. Dr., Selçuk Üniversitesi, \\ İktisadi ve İdari Bilimler Fakültesi, İşletme Bölümü \\ adnancelik@selcuk.edu.tr \\ Orcid ID: https://orcid.org/0000-0002-8538-9937
}

\begin{abstract}
Öz
Genellikle kamu ve siyaset bilimi gibi alanlarda ele alınan demokrasi kavramı, modern yönetim yaklaşımının insana verdiği değer ile birlikte, işletme, eğitim, turizm, sağ lık gibi yönetim bilimi ile ilgilenen farklı alanlarda da ele alınmıştır. Yönetimde otoriter yaklaşımlardan çok, karar alma süreçlerine örgüt üyelerinin de dâhil edildiği katılımcı yaklaşımları öngören örgütsel demokrasi, akademik yazında her geçen gün daha da önemli hale gelmiştir. Bu araştırmanın amacı, örgütsel demokrasi alanında hazırlanan lisansüstü tezler ve makalelere ilişkin farklı disiplinlerde hazırlanan çalışmaların yöntemleri, ele alınan değişkenleri ve hazırlanan çalışmalarda yer alan neden sonuçlarına ilişkin bilgileri ortaya koymaktır. Bu kapsamda başlıkla arama yapılarak ulaşılan, YÖK Ulusal Tez Merkezinde yer alan 20 lisansüstü tez, TR dizin veri tabanında 5 makale ve Dergipark veri tabanında yer alan 12 makale içerik analizi yöntemiyle incelenmiştir. Araştırma sonucunda, konuya ilişkin araştırmaların daha çok 2019 yılından itibaren yoğunlaştığı gözlemlenmiştir.
\end{abstract}

Anahtar Kelimeler: Örgütsel Demokrasi, Yönetim ve Organizasyon, Katılımcı Yönetim, İçerik Analizi.

\footnotetext{
${ }^{1}$ Makale Geliş/Kabul Tarihi: 13.04.2021 / 28.07.2021

Künye Bilgisi: Korkmaz, E. V. ve Çelik, A. (2020). Katılımcı yönetimde önemli bir kavram olarak örgütsel demokrasiye ilişkin; Ulusal Tez Merkezi, TR Dizin ve Dergipark veri tabanları kapsamında bir içerik analizi. Kahramanmaraş Sütçü Imam Üniversitesi Sosyal Bilimler Dergisi, 18(2), 1303-1321. DOI: 10.33437/ksusbd.915548
} 


\title{
A Content Analysis on Organizational Democracy As an İmportant Concept in Participatory Management within the Scope of The National Thesis Center, TR Dizin and Dergipark Databases
}

\begin{abstract}
The concept of democracy, which is generally handled in fields such as public and political science, has also been addressed in different areas dealing with management science such as business, education, tourism, health, together with the value of modern management approach to people. Organizational democracy, which envisages a participatory approach in which members of the organization are included in decision-making processes, rather than authoritarian methods in management, has become more and more important every day. The aim of this research is to reveal the researches, methods, variables dealt with in different disciplines about postgraduate theses and articles prepared in the field of organizational democracy and the information about the cause and effect in the studies. In this context, 20 graduate theses in YOK National Thesis Center, 5 articles in TR Index database and 12 articles in Dergipark database, which can be reached by searching by title, have been analyzed by content analysis method. As a result of the research, it has been observed that the researches on the subject have intensified since 2019.
\end{abstract}

Keywords: Organizational Democracy, Management and Organization, Participatory Management, Content Analysis.

\section{GíRIŞ}

İş dünyasında insancıl yaklaşımların her geçen gün önem kazanması, yöneticilerin kararlara katılım konusunda çalışanlarının fikirlerini göz önüne alan tutumlar sergileme konusunda istekli davranmaları, son zamanlarda örgütsel demokrasi kavramının daha da önemli bir hale gelmesine neden olmuştur. Örgütsel demokrasi, örgüt içerisinde çalışanlar ve yöneticilerin, demokratik bir ortamda bilgi alışverişinde bulunabilmelerine olanak veren bir örgüt ortamının varlığıdır. Bu demokratik ortam, örgütteki bireylerin örgüt içi düzenlemelere ve alınacak kararlara dâhil olmalarını ve bu doğrultuda örgütlerine güvenmelerini, bağlılıklarının artmasını ve işe yönelik tatminlerinin artmasını destekleyen önemli bir güçtür. Örgütsel demokrasi örgütlere, bilginin etkili bir iletişim ortamında paylaşımını, çalışanların eğitim imkânları ile desteklenerek yaratıcı ve yenilikçi davranışlarının gelişmesini, çalışanların yeteneklerini daha rahat bir biçimde ortaya çıkarabilecekleri bir örgüt ortamında görevlerini yüksek motivasyonla verimli bir şekilde gerçekleştirebilmelerini sağlar. 
Dünya geneline baktığımızda örgütsel demokrasi konusu üzerine hazırlanmış tez ve bilimsel çalışma sayısı her geçen gün artmaktadır. Bu çalışmada Türkiye örnekleminde Uluslararası Tez Merkezi, TR Dizin ve Dergipark veri tabanlarındaki çalışmalar ele alınacaktır. Veri tabanlarının arama linkine tırnak içerisinde "örgütsel demokrasi" kavramı yazılarak, kavramın sadece başlıkta geçtiği çalışmalar ele alınmış ve çalışmaların genel yapıları ortaya konmak istenmiştir. Türkiye geneli Uluslararası Tez Merkezi, TR Dizin ve Dergipark veri tabanlarına baktığımızda, akademik yazında örgütsel demokrasi kavramı ile ilgili çalışma sayısının 2019 yılından önce çok az sayıda olduğu, en çok yayının 2019 yılında yapıldığ 1,2020 yılında da konunun yoğun bir şekilde araştırılmaya devam edildiği gözlemlenmiştir.

\section{Literatür Taraması}

Demokrasi terimi klasik Yunancadan gelmektedir. Demokratik, insanlar anlamına gelen demos ve güç, güç ve otorite anlamına gelen kratos unsurlarının birleşimidir. $\mathrm{Bu}$ nedenle, demokrasi insanların gücü anlamına gelmektedir. Örgütsel demokrasi ise eşitlik, karar verme ve işbirliği gibi tanımları içermektedir. Demokratik bir örgüt, üyelerini, sosyal değişimleri ve diğer paydaşlarla işbirliğini potansiyel bir güç olarak görür. Endüstriyel ve demokratik örgütler arasında bazı farklar mevcuttur (Safari, Salehzadeh ve Ghaziasgar, 2017: 76).

Tablo 1. Demokratik ve Endüstriyel Örgütler Arasındaki Farklar

\begin{tabular}{|l|l|}
\hline \multicolumn{1}{|c|}{ Demokratik Örgüt } & \multicolumn{1}{c|}{ Endüstriyel Örgüt } \\
\hline $\begin{array}{l}\text { Her düzeyde kararlar alınır ve } \\
\text { organizasyon yapısı yataydır. }\end{array}$ & $\begin{array}{l}\text { Kararlar yönetimde veya yüksek yetki } \\
\text { seviyelerinde alınır ve organizasyon } \\
\text { yapısı katı ve hiyerarşiktir. }\end{array}$ \\
\hline $\begin{array}{l}\text { Liderler farklı paydaşlar tarafından } \\
\text { değerlendirilir. }\end{array}$ & $\begin{array}{l}\text { Liderler başkaları tarafından } \\
\text { değerlendirilmez. }\end{array}$ \\
\hline $\begin{array}{l}\text { Tüm seviyeler katılmaya teşvik } \\
\text { edilir ve geribildirim verir. }\end{array}$ & $\begin{array}{l}\text { Çalışanlardan yönergeye uymaları } \\
\text { beklenir. }\end{array}$ \\
\hline Çeşitlilik teşvik edilir. & $\begin{array}{l}\text { Normlar, davranışlar ve faaliyetler } \\
\text { önceden belirlenir ve yakından } \\
\text { dikkatle incelenir. }\end{array}$ \\
\hline
\end{tabular}




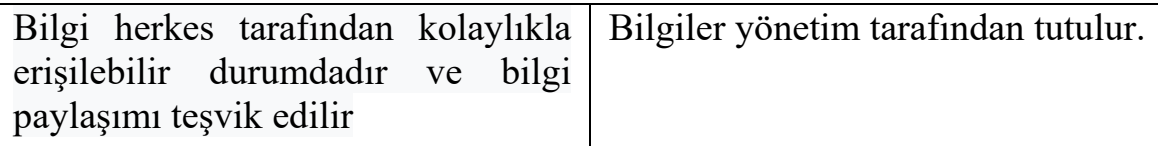

Kaynak: Akt: Safari, Salehzadeh ve Ghaziasgar, 2017: 76.

Örgütsel demokrasi kavramı, sanayi devrimiyle artan makineleşme sonucu, işçilerin iş koşullarına ilişkin haklarının gündeme gelmesi ve bunun sonucunda sendikaların çalışanların kurumlarda hakları ve alınacak kararlarda söz sahibi olmaları yönündeki taleplerinin gündeme getirilmesi ile ortaya çıkmıştır. 19.yüzyıl sonrasında ise örgütsel demokrasi kavramı, sendikal hakların da ötesinde, çalışanların kararlara katılımını ve yönetim işlerinde söz sahibi olmalarını öngören bir gelişim yaşamıştır (Öztürk ve Demirtaş, 2019: 11). Son yirmi yılda bilim adamları, örgütlerde demokratik uygulamaların ve fikirlerin hayata geçmesi, çalışanların tutum ve davranışlarında önemli gelişmeler ortaya çıkardığını çalışmaları ile ortaya koymuşlardır (Ahmed, Adeel, Ali ve Rehman, 2018: 1$)$.

Eğitim destekli, katılımcı ve iş birliği sürecine dayalı demokratik karar alma süreçleri, yetenekli personellerin yeteneklerini ortaya çıkarmalarını teşvik eder. İşücü ne kadar çok eğitilip karar alma süreçlerine katılım konusunda motive edilirse, örgütsel demokrasi de o kadar başarılı olur (Hanison ve Fieeman, 2004: 52). Örgütsel demokrasinin hâkim olduğu örgütlerde; çalışanlar uzun vadeli stratejik hedefler veya en azından orta vadeli taktiksel hedefleri belirlemede kollektif bir anlayış imkânına sahiptirler (Verdorfer ve Weber, 2016: 68). Bu nedenle birçok araştırma göstermektedir ki örgütsel demokrasinin önem verildiği kurumlarda çalışanlar, katılımcı yönetim anlayışı sayesinde kararlara katıldığ 1 için sorumlulukla çalışan, araştıran, yeni fikirlere açık olan ve bu fikirleri kurumuna kolaylıkla aktaran özelliktedirler.

\section{Araştırmanın Amacı ve Önemi}

Örgüt ortamında demokratik bir yönetim bilincinin önemini ifade eden örgütsel demokrasi konusuna ilişkin bilincin artması, katılımcı yönetim anlayışının örgütlerde daha çok benimsenmesi açısından önemlidir. Araştırmalar göstermektedir ki, bu bilinci arttırmak; örgütlerdeki demokrasi temelli yaklaşımları arttıracağı gibi, verimlilik, iş tatmini, motivasyon gibi konuları da etkileyeceği için, kavram irdelenmesi gereken önemli bir konudur.

$\mathrm{Bu}$ çalışmada, kavrama ilişkin hangi disiplinlerde çalışmaların yapıldığı, çalışmalarda yararlanılan metotların neler olduğu ve örgütsel demokrasi kavramına ilişkin çalışmalardaki neden-sonuçların ne şekilde geliştiği gibi üç temel soruya veri tabanlarından alınan çalışmalara uygulanacak içerik analizi yöntemi ile cevap aranması amaçlanmıştır. 


\section{Araştırmanın Yöntemi}

Ulusal Tez Merkezi aracılığ ile ulaşılan lisansüstü tez dokümanları, Ulakbim TR dizin ve Dergipark veri tabanından ulaşılan makale çalışmalarının ele alınması kapsamında hazırlanan bu çalışmada, yöntem olarak içerik analizinden faydalanılmıştır. Gazete haberlerinin derlenmesi ile 16. yüzyılda kullanıma başlanan içerik analizi, bugün birçok bilimsel çalışmada sıklıkla kullanılan bir yöntemidir (Çilingir, 2017: 149). İçerik analizi yöntemi, deneysel problemlere ilişkin istatistiki formüller geliştirmeyi amaçlamaktadır (Kaplan, 1943: 230).

\section{Bulgular ve Analizler}

İçerik analizi yöntemi ile ele alınan lisansüstü tezler ve makaleler YÖK Ulusal Tez Merkezi, TR dizin ve Dergipark veri tabanlarından elde edilmiştir. "Örgütsel demokrasi” kelimesi, konuyla tam ilgisi olan çalışmalara ulaşmak adına, çalışmaların isminde aranarak taranmıştır. Ulusal Tez merkezinde isminde "örgütsel demokrasi” kelimesi yer alan toplam 20 lisansüstü tez, TR dizin veri tabanında isminde "örgütsel demokrasi" kelimesi yer alan toplam 5 makale ve Dergipark veri tabanında isminde "örgütsel demokrasi" kelimesi yer alan toplam 12 makale çalışmasına ulaşılmış ve incelemeye tabi tutulmuştur. Yıllar itibari ile yapılan çalışmalar değerlendirildiğinde, bu veri tabanlarından elde edilen bilgilere göre, örgütsel demokrasi konusunda yapılan ilk çalışmanın 2010 yılında eğitim alanında hazırlanan bir yüksek lisans tezine ait olduğu gözlemlenmiştir.

\section{Örgütsel Demokrasi Konusuna İlişkin Veri Tabanlarında Yer Alan Tez ve Makalelerde Kullanılan Anahtar Kelimelere Yönelik Bulgular}

Akademik çalışmalarda tercih edilen anahtar kelimeler, araştırmada kullanılan değişkenler, araştırmanın ana fikri, örneklemi ve araştırmada kullanılan yöntemler hakkında kısa bilgi veren kavramlardır. $\mathrm{Bu}$ çalışmada veri tabanlarından ulaşılan tez ve makale çalışmalarında anahtar kelime olarak "örgütsel demokrasi" kavramı harici, toplamda 72 farklı anahtar kelime daha kullanılmıştır. En çok kullanılan bazı anahtar kelimelere baktığımızda; demokrasi $(\mathrm{n}=8, \% 11,1)$, örgütsel bağlllık $(\mathrm{n}=8, \% 11,1)$, örgütsel muhalefet $(\mathrm{n}=7, \% 9,7)$, örgütsel vatandaşlık $(\mathrm{n}=4, \% 5,5)$, ögretim elemanı $(\mathrm{n}=4, \% 5,5)$, muhalefet $(\mathrm{n}=3$, $\% 4,1)$, örgütsel sinizm $(n=3, \% 4,1)$ ve iş tatmini $(n=3, \% 4,1)$ olduğu belirlenmiştir. $\mathrm{Bu}$ anahtar kelimeler arasında demokrasiden sonra örgütsel bağl1lık kelimesinin fazla kullanılması beklenen bir durum olarak düşünülebilir. Örgütsel demokrasi konusunda çalışma yapan araştırmacılar, örgütsel demokrasinin varlığı ile örgüte olan bağlılığın artacağını belirtmişlerdir (Demirtaş, 2017; Uysal, 2019). Örgütsel bağl1lı̆̆ın ardından en çok kullanılan diğer anahtar kelimeler; örgütsel muhalefet ve muhalefet kelimeleridir. Örgütsel muhalefet 4 tez ve 3 makaleye, muhalefet kelimesi 3 teze anahtar kelime olmuştur. Sadykova ve Tutar (2014: 3) zıt düşüncelerin de açık bir şekilde ifade 
edilebilmesi anlamına gelen muhalefet kavramının, örgütsel demokrasi açısından önem arz ettiğini çalışmalarında belirtmişlerdir.

\section{Örgütsel Demokrasi Konusunda Hazırlanan Tez ve Makale Yazarlarının Bağlı Oldukları Birimlere Göre Dağılımları}

Ulusal Tez Merkezi, TR Dizin ve Dergipark veri tabanlarında yer alan örgütsel demokrasi konusuna ilişkin tez ve makalelerin yazarlarının bağlı bulundukları üniversitelere göre dağılımları Tablo 2'de yer almaktadır. 20 ildeki 29 üniversitede, yani illerin \%24,6'sında, üniversitelerin \%13,9'luk bir kısmında örgütsel demokrasi konusuna ilişkin en az bir tez veya makale çalışması yapılmıştır. Yazarların illere göre dağılımında, konu hakkında çalışma yapmış yazar sayısına göre illerde ilk sırada Isparta $(n=4)$ ve Manisa $(n=4)$ vardır.

Tablo2. Tez ve Makale Yazarlarının Bağlı Oldukları Birimlere Göre Dağılımları

\begin{tabular}{|c|c|c|c|c|}
\hline \multirow[b]{2}{*}{ Okul Adı } & \multicolumn{2}{|c|}{$\begin{array}{c}\text { Ulusal Tez } \\
\text { Merkezi } \\
\text { Lisansüstü } \\
\text { Tez }\end{array}$} & \multicolumn{2}{|c|}{ Makale } \\
\hline & YL & Dr & Dergipark & TR Dizin \\
\hline Adnan Menderes Üniversitesi & & & 1 & 1 \\
\hline Akdeniz Üniversitesi & & 1 & & \\
\hline Ankara Üniversitesi & & 1 & & \\
\hline Başkent Üniversitesi & & 1 & & \\
\hline Balıkesir Üniversitesi & & & 1 & 1 \\
\hline Beykent Üniversitesi & 1 & & & \\
\hline Burdur Mehmet Akif Ersoy Üniversitesi & 1 & & & \\
\hline \multicolumn{5}{|l|}{ Cumhuriyet Üniversitesi } \\
\hline Hacettepe Üniversitesi & 1 & 1 & & \\
\hline Haliç Üniversitesi & 1 & & & \\
\hline İnönü Üniversitesi & & 1 & & 1 \\
\hline İstanbul Üniversitesi & & 1 & 2 & \\
\hline İstanbul Gelişim Üniversitesi & 1 & & & \\
\hline İstanbul Ticaret Üniversitesi & & 1 & & \\
\hline $\begin{array}{lll}\begin{array}{l}\text { Kahramanmaraş } \\
\text { Üniversitesi }\end{array} & \text { Sütçü } & \text { İmam } \\
\end{array}$ & & & 2 & \\
\hline Kilis 7 Aralık Üniversitesi & & & 1 & \\
\hline
\end{tabular}


E.V.Korkmaz-A.Celik Katılımcı Yönetimde Önemli Bir Kavram...

\begin{tabular}{|l|c|c|c|c|}
\hline Kocaeli Üniversitesi & & & & 2 \\
\hline Manisa Celal Bayar Üniversitesi & & 1 & 3 & \\
\hline Marmara Üniversitesi & 1 & & & \\
\hline Muğla Sıtkı Koçman Üniversitesi & & & 1 & 1 \\
\hline Necmettin Erbakan Üniversitesi & & & 1 & 1 \\
\hline Nevşehir Hacı Bektaş Veli Üniversitesi & & 1 & 1 & 1 \\
\hline ODTÜ Geliştirme Vakfı Okulları & & & & \\
\hline Okan Üniversitesi & & & & \\
\hline Osmaniye Korkut Ata Üniversitesi & & & & \\
\hline Sakarya Üniversitesi & & & & \\
\hline Süleyman Demirel Üniversitesi & 1 & & & \\
\hline Toros Üniversitesi & 1 & & & \\
\hline Yüzüncü Yıı Üniversitesi & 1 & & & \\
\hline
\end{tabular}

Şekil 1'de Ulusal Tez Merkezinde incelenen örgütsel demokrasi konusuna ilişkin hazırlanan tezlerin enstitülerine göre dağılımına bakıldığında; Sosyal Bilimler Enstitüsü (n=13), Eğitim Bilimleri Enstitüsü $(n=5)$ ve Lisansüstü Eğitim Enstitüsü $(\mathrm{n}=2)$ şeklindedir. Toplanan veriler göstermektedir ki, tezler toplam 6 anabilim dalında hazırlanmıştır. Bunlardan \%50'si işletme anabilim dalında, \%30'u eğitim anabilim dalında, \%10'u turizm anabilim dalında, \%5'i çalışma ekonomisi ve endüstri ilişkileri anabilim dalında, \%5'i hemşirelikte yönetim anabilim dalında hazırlanmıştır.

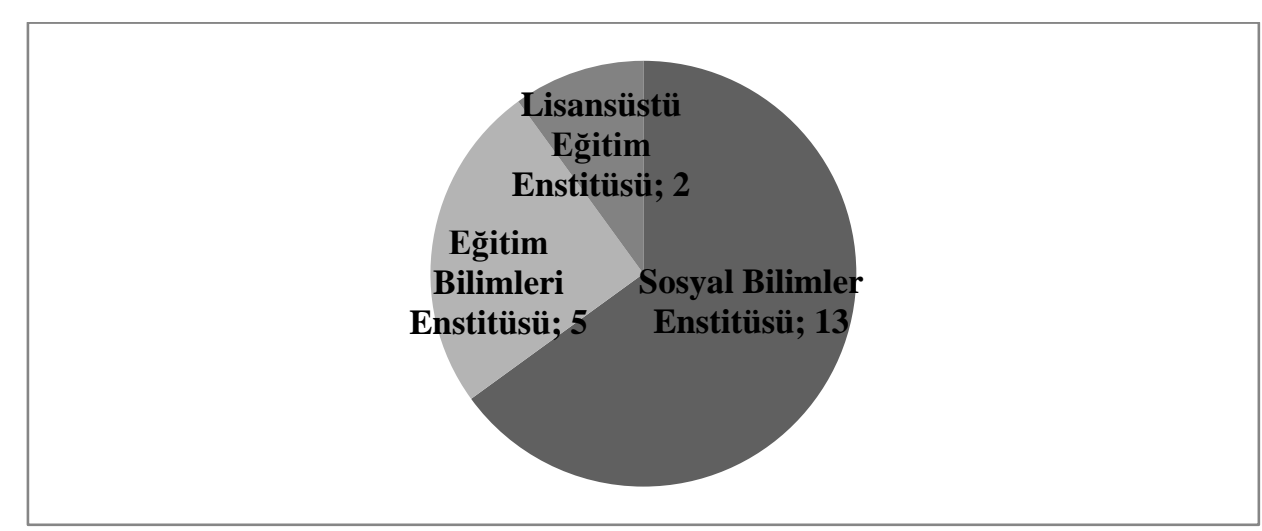

Şekil 1. Örgütsel Demokrasi Konusundaki Tez Çalışmalarının Enstitülere Göre Dağglımı 


\section{Veri Tabanlarında Yer Alan Örgütsel Demokrasi Çalışmalarının Yıllara Göre Dağılımları}

Şekil 2.'de Ulusal Tez merkezi, TR Dizin ve Dergipark veri tabanlarında örgütsel demokrasiye konusuna ilişkin lisansüstü tez ve makalelerin yıllara göre dağılımı yer almaktadır. Bu doğrultuda yıllar itibari ile bakıldığında; örgütsel demokrasi konusu hakkında 5 yüksek lisans tezi, 3 doktora tezi ve 1 Dergipark park veri tabanında yer alan makale çalışması ile en fazla çalışmanın yapıldığ yılın 2019 olduğu gözlemlenmiştir. En çok yayın yapılan ikinci yıl; 1 yüksek lisans tezi, 1 TR Dizin veri tabanındaki makale ve 6 Dergipark veri tabanındaki makale ile 2017 yılıdır. Konuya ilişkin ilk çalışma 2010 yılında bir yüksek lisans çalışmasına aittir. 2011 ve 2016 yıllarında örgütsel demokrasi konusuna ilişkin Ulusal Tez Merkezi, TR Dizin ve Dergipark veri tabanlarında herhangi bir çalışmaya ulaşılamamıştır.

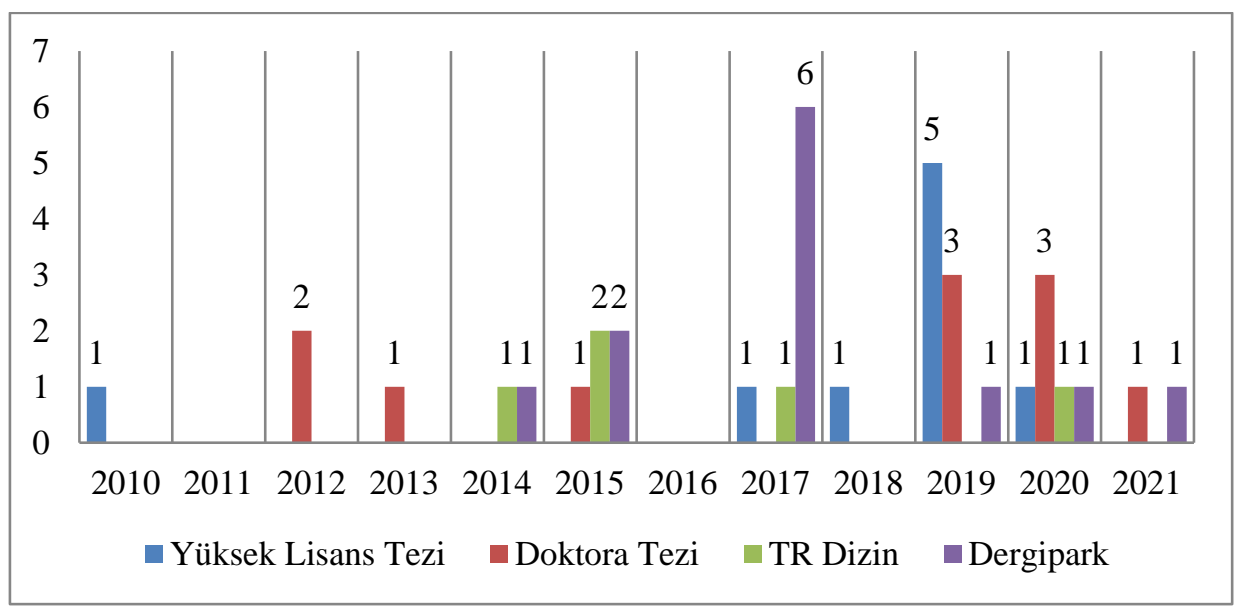

Şekil 2. Yıllara Göre Örgütsel Demokrasi Çalışmalarının Dağılımları

\section{Veri Tabanlarında Yer Alan Örgütsel Demokrasi Çalışmalarına İlişkin Araştırma ve Veri Analiz Yöntemleri}

Çalışmalarda kullanılan araştırma yöntemlerinin Şekil 3'de dağılımına baktı̆̆ımızda; Ulusal Tez Merkezinde yer alan 20 lisansüstü tezin 18'i nicel araştırma (anket), 2 tanesinde karma yöntem (anket ve görüşme) kullanılmıştır. Dergipark veri tabanındaki çalışmalara bakıldığında 12 makale çalışmasının 1 tanesinin kavramsal çalışma 11 tanesinin nicel çalışma olduğu gözlemlenmiştir. TR Dizin veri tabanında yer alan 5 makale çalışmasının 1'i kavramsal 4'ü nicel araştırmadır. Veri toplama yöntemi olarak en çok kullanılan araç, ankettir. Karma yöntem kullanılan lisansüstü tezlerin 2'sinde ankete ek olarak görüşme tekniği de kullanılmıştır. 
Veri tabanlarından elde edilen çalışmalarda belirtilen bilgilere göre Şekil 3' de; Ulusal Tez Merkezindeki tez çalışmalarının \%100'ünde $(n=20)$ Cronbach Alpha değeri hesaplanmış, \%85'inde $(\mathrm{n}=17)$ regresyon analizi, \%70'inde $(\mathrm{n}=14)$ ANOVA ve \%70’inde ( $\mathrm{n}=14)$ faktör analizi yapılmıştır.

Örgütsel demokrasi konusuna ilişkin Dergipark veri tabanında yer alan 12 makale çalışmasının analiz yöntemlerine göre dağılımlarına Şekil 3'de bakıldığında; \%91,6'sında ( $\mathrm{n}=11)$ Cronbach Alpha değeri hesaplanmış, \%91,6 $(\mathrm{n}=11)$ ile en çok korelasyon analizi yapılmış, \% 75 'inde $(\mathrm{n}=9)$ regresyon analizi, $\% 50$ 'sinde $(\mathrm{n}=6)$ ANOVA yapılmıştır.

TR Dizin veri tabanındaki 5 makale çalışmasına Şekil 3'de bakıldığında; \%80'inde Cronbach Alpha $(\mathrm{n}=4)$ hesaplanmış, \%80'inde en çok korelasyon analizi yapıldığı gözlemlenmiştir.

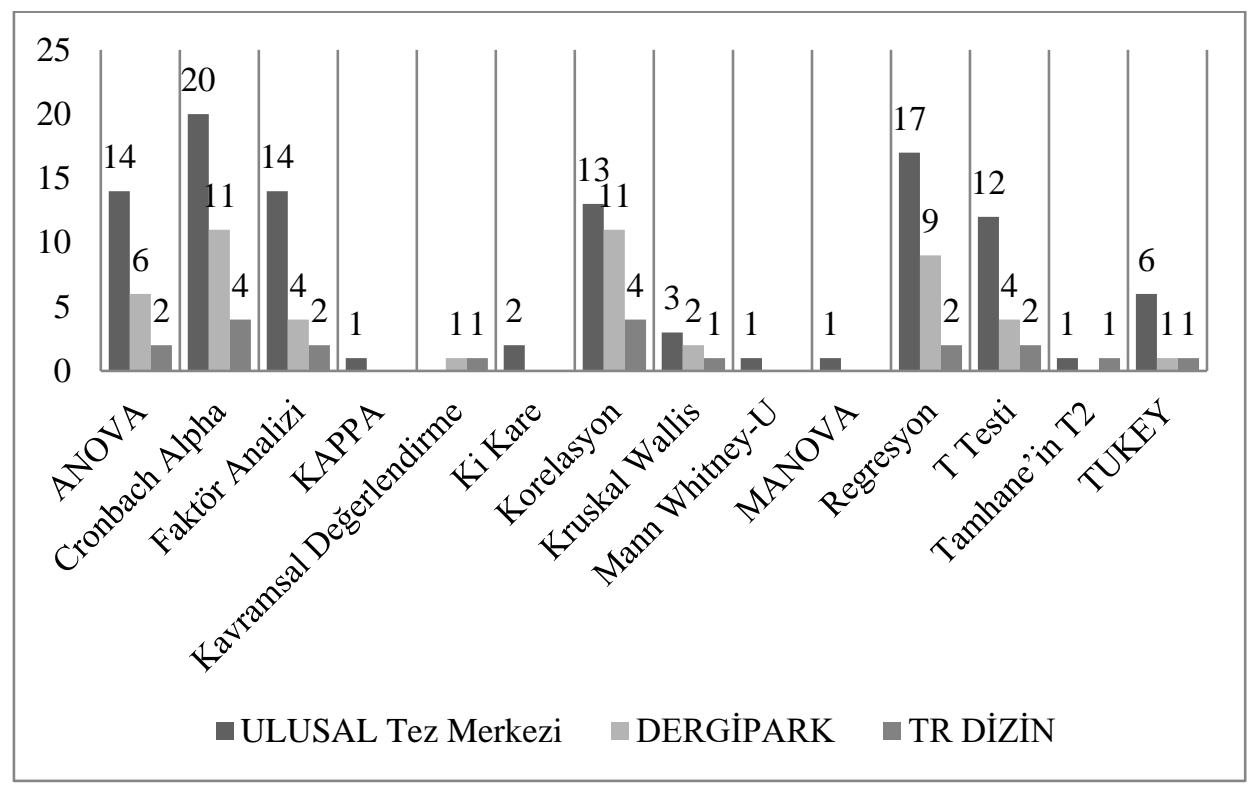

Şekil 3. Örgütsel Demokrasi Araştırmalarında Kullanılan Analiz Yöntemleri

\section{Veri Tabanlarında Yer Alan Örgütsel Demokrasi Çalışmalarının Örneklem Büyüklüklerine İlişskin Bulgular}

Şekil 4'de veri tabanlarından elde edilen örgütsel demokrasi konusunda hazırlanan çalışmalarda belirtilen örneklem gruplarına ilişkin bilgilere göre; Ulusal Tez Merkezi, Dergipark ve TR Dizinde yer alan çalışmalarda en çok 
öğretim elemanı $(\mathrm{n}=1611)$ örneklem grubu üzerine çalışma yapıldı̆̆ 1 gözlemlenmiştir. Öğretim elemanı örneklem grubunu, beyaz yakalı çalışanlar $(\mathrm{n}=1567)$, öğretmenler $(\mathrm{n}=1524)$ ve sağlık çalışanları $(\mathrm{n}=1440)$ takip etmektedir. Çalışmalardaki örneklem gruplarının dağılımı Şekil 4'deki gibidir;

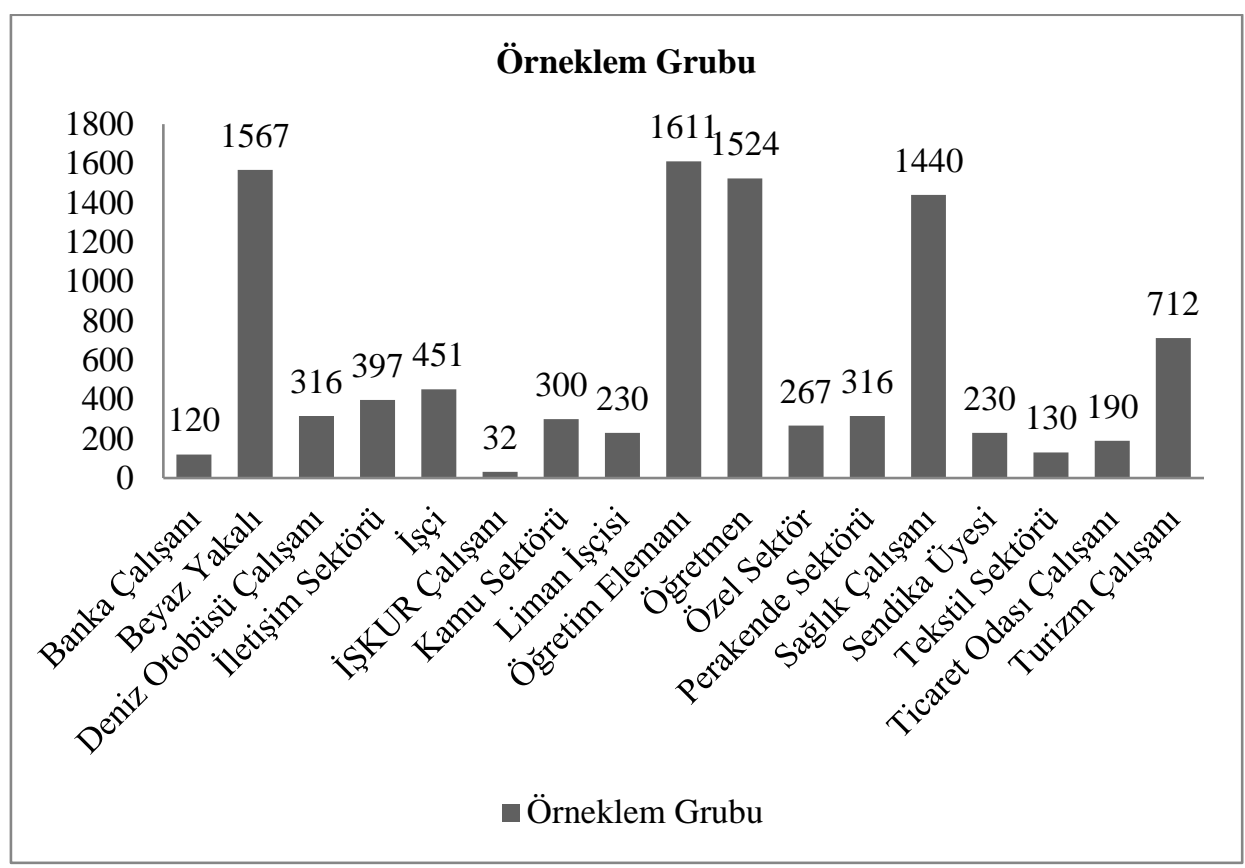

Şekil 4. Veri Tabanlarında Yer Alan Örgütsel Demokrasi Çalışmalarının Örneklem Büyüklüklerine Göre Dağılımı

\section{Veri Tabanlarında Yer Alan Örgütsel Demokrasi Çalışmalarının Bağımlı Değişkenlerine İlişkin Bulgular}

Veri tabanlarından elde edilen çalışmalarda belirtilen bilgilere göre; Ulusal Tez Merkezi, Dergipark ve TR Dizinde yer alan çalışmalarda ele alınan bağımlı değişkenlerin dağılımına Şekil 5.'e baktığımızda örgütsel demokrasi konusunun en çok örgütsel muhalefet $(n=5)$ üzerine etkisi araştırılmış ve bu kavram çalışmalarda en fazla kullanılan bağımlı değişken olarak kullanılmıştır. Örgütsel muhalefet bağımlı değişkeninden sonra en çok kullanılan diğer iki bağımlı değişken; politik davranışlar $(n=3)$ ve örgütsel vatandaşlık $(n=3)$ değişkenleridir. Çavuş ve Biçer (2021) çalışmalarında; örgütsel demokrasi değişkeninin örgütsel vatandaşlık davranışı arasındaki ilişkileri test etmek için korelasyon ve basit regresyon analizleri yapılmışlardır. Korelasyon analizinin sonuçları, hem 
örgütsel demokrasi hem de örgütsel vatandaşlık davranışının alt boyutları arasında pozitif ve istatistiksel olarak anlamlı ilişkiler olduğunu ortaya koymuştur. Değiş̧kenler arasındaki korelasyon, örgütsel demokrasi algısının örgütsel vatandaşlık davranışına olumlu katkılar yarattığını ortaya koymaktadır. Daha açık bir ifadeyle, demokratik yönetim uygulamalarının yarattığı olumlu algı düzeyi arttıkça, çalışanların koşulsuz olarak kendilerini organizasyonun bir parçası olarak hissetmelerine bağlı olarak davranışlarında olumlu değişiklikler olacaktır sonucuna ulaşmışlardır. Erdal (2020) hazırladığı yüksek lisans tezinde; örgütsel demokrasi ve örgütsel muhalefet arasında pozitif yönlü anlamlı bir ilişki bulmuştur. Örgütsel demokrasiyi açıklamada örgütsel muhalefet değişkenin önemli olduğunu yazına eklemiştir.

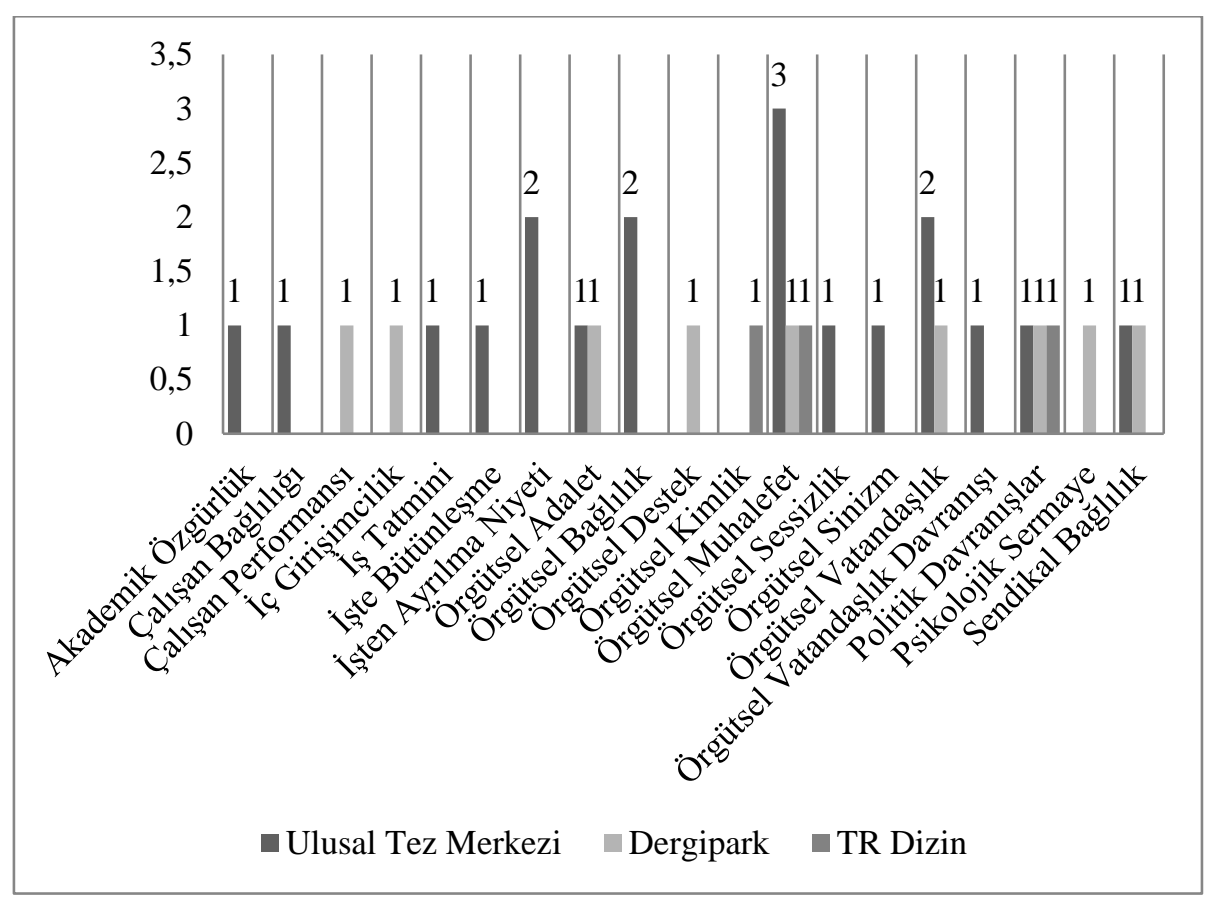

Şekil 5. Veri Tabanlarında Yer Alan Örgütsel Demokrasi Çalışmalarının Bağımlı Değişkenlerine İlişkin Bulgular

Bakan, Güler ve Kara'nın (2017: 1040) turizm çalışanları üzerine yaptıkları çalışmalarında, katılımcıların örgütsel demokrasi algısı arttıkça, örgütsel adalet ve örgütsel destek algılarının da arttığına ilişkin sonuçlara ulaşmışlardır. 


\section{Veri Tabanlarında Yer Alan Örgütsel Demokrasi Çalışmalarının Bağımsız Değişkenlerine İlişkin Bulgular}

Veri tabanlarından elde edilen çalışmalarda belirtilen bilgilere göre; Ulusal Tez Merkezi, Dergipark ve TR Dizinde yer alan çalışmalarda ele alınan bağımsız değişkenlerin dağılımına Şekil 6'ya baktığımızda örgütsel demokrasi kavramı toplamda 33 bağımsız değişken ile birlikte araştırmaya tabi tutulmuştur. $\mathrm{Bu}$ bağımsız değişkenler içerisinde en çok kullanılan bağımsız değişken yaştır $(n=17)$. Yaş değişkenin ardından örgütsel demokrasi kavramı ile en çok kullanılan bağımsız değişkenler; cinsiyet ( $\mathrm{n}=16)$, eğitim durumu $(\mathrm{n}=15)$, medeni durum ( $\mathrm{n}=13)$ ve unvan-görev-pozisyondur $(\mathrm{n}=10)$.

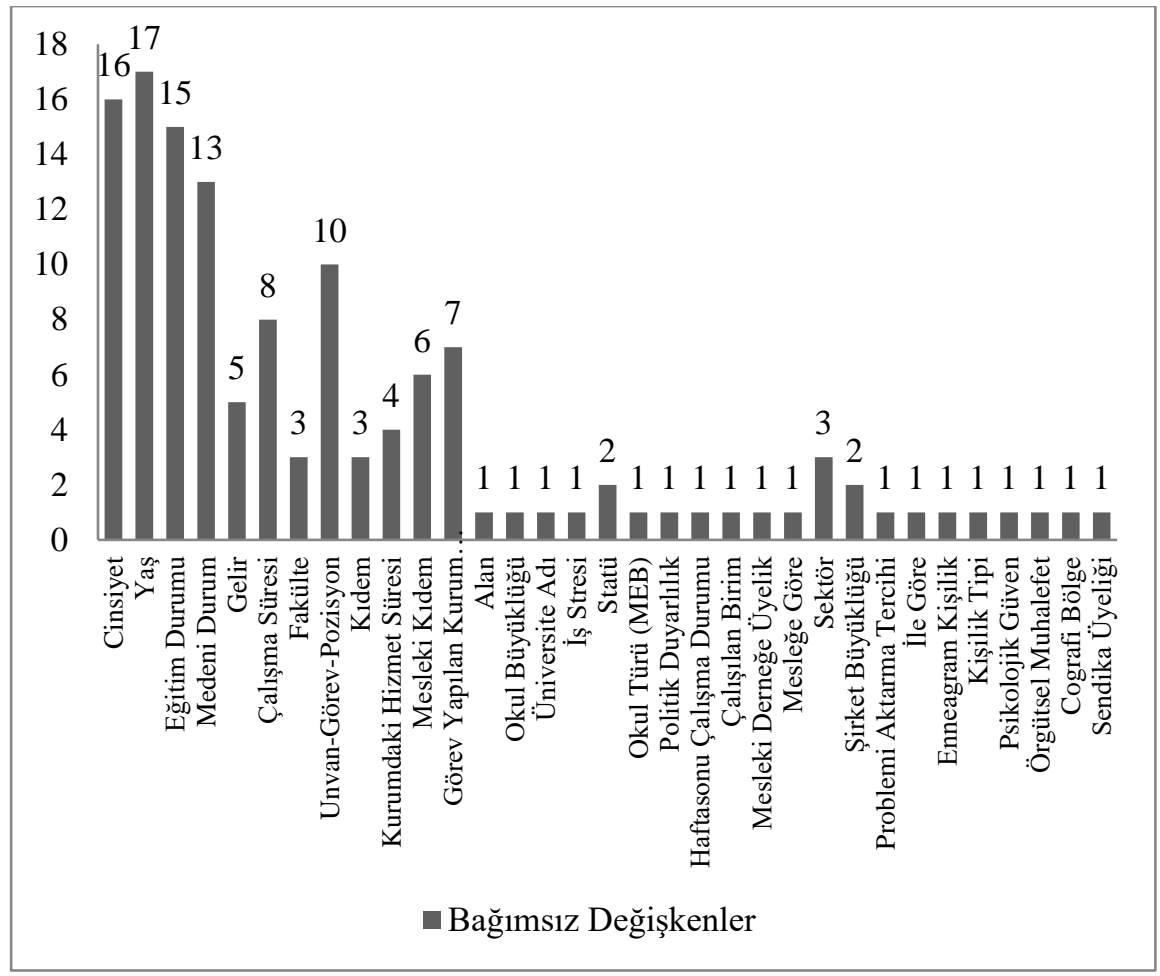

Şekil 6. Veri Tabanlarında Yer Alan Örgütsel Demokrasi Çalışmalarının Bağımsız Değişkenlerine İlişkin Bulgular

Çopur ve Baskan (2020) çalışmalarında, cevaplayıcıların örgütsel demokrasiye yönelik görüşlerine ilişkin farklılık testleri sonucu; cinsiyet bağımsız değişkenine göre farklılaşmadığı fakat medeni durum, görev yaptıkları üniversite, akademik kadroları ve unvanlarına göre farklılaştığı sonucuna ulaşmışlardır. Profesörlerin örgütsel demokrasi algısının Yardımcı Doçent ve 
Araştırma Görevlilerinden daha yüksek olduğu sonucuna ulaşmıştır. Erdal (2020: 115) örgütsel demokrasi algısının cinsiyete, yaşa, medeni duruma, görev kademesine ve kıdeme göre farklılık oluşup oluşmadığını test etmiş ve sonuç olarak bu bağımsız değişkenlerde herhangi bir anlamlı farklılığa ulaşamamıştır. Can (2020) doktora tezinde turizm eğitimi veren akademisyenlerin örgütsel demokrasi algıları ile yaşları ve eğitimleri arasındaki farklılığı araştırması sonucu; yaş ve eğitim bağımsız değişkenleri ile örgütsel demokrasi algıları arasında anlamlı bir farklılaşmanın olduğu sonucunu bildirmiştir.

Şeker (2010) yüksek lisans tezinde yönetici ve öğretmenlerin örgütsel demokrasi algılarının cinsiyete göre farklılaşmadığı, alana göre farklılaştı̆̆ 1 sonucuna ulaşmıştır. Sınıf öğretmenlerinin branş öğretmenlerine göre daha olumlu bir örgütsel demokrasi algısına sahip olduklarını ortaya koymuştur.

\section{Sonuç}

Araştırmanın son sorusu örgütsel demokrasi konusuna ilişkin çalışmalarda çözüm yöntemlerinin neler olduğudur. $\mathrm{Bu}$ doğrultuda ilk olarak örgütsel demokrasi konusu ile en çok ele alınan örneklem grubu olan öğretim elemanlarına ilişkin sonuçlar dikkat çekmektedir. Bozkurt (2012) doktora tezinde örgütsel demokrasi ortamı için; üniversite yönetiminde yer alanların ayrımcı tutumlardan uzaklaşması, yönetim mekanizmasının karar süreçlerinde hesap verebilir bir yapıda olması, fakültelerin kendi kapasitelerinde öğrenci sayılarını belirlemeleri, dekanlık vb. yönetim basamaklarında seçimlerin oylama ile yapılması, bu seçim süreçlerine fakülte akademik personeli yanında öğrenci ve diğer tüm paydaşların dâhil olması gerektiği bilgilerini paylaşmıştır. Ayrıca Çopur ve Baskan (2020) profesörlerin örgütsel demokrasi algısının yardımcı doçent ve araştırma görevlilerinden yüksek olmasını, akademik kariyerinin ilk yıllarında daha idealist ve beklentilerinin yüksekliği nedeniyle ortama uyum sağlamada sorunlar yaşatabileceğini ifade etmiştir. Fakat zamanla mesleğin gereklilikleri ve inceliklerine ilişkin deneyim ve tecrübelerin artması ile örgütsel demokrasi konusuna bakış açılarının da gelişeceğini ifade etmiştir. Turabik (2019: 170) öğretim elemanları üzerine hazırladığı doktora çalışmasıyla örgütsel demokrasinin, örgütlerde herhangi bir işlev yaratmayan politik davranışların azalmasına destek olduğu sonucuna ulaşmıştır. Örgütsel demokrasinin bu doğrultuda kuruma destek olabilmesi için de;

-Rektör, dekan ve bölüm başkanları gibi yönetim kademelerinin, örgütsel demokrasiyi örgüt kültürü olarak kabul etmeleri,

-Örgüt içi kaynak dağılımında hakkaniyetli olmaları,

-Gerektiğinde güç kaynaklarının paylaşılabilmeleri, 
-Yönetim kademesinde gerçekleşen işlerin şeffaf, açık ve hesap verebilir olarak yürütülmesi gerektiğini vurgulamıştır.

Örgütsel demokrasi konusunda en fazla ele alınan değişkenlerden biri de örgütsel muhalefettir. Erkasap (2020: 188) çalışmasında, örgütsel demokrasi algılamalarının çalışanlarının örgütsel muhalefet değişkeni üzerine pozitif bir etkiye sahip olduğu sonucuna ulaşmıştır. Ayrıca demokrasi konusunda farklı düşünceleri dile getirebilme durumu olan örgütsel muhalefet durumunu, çeşitli kişilik tipleri ile ele almıştır. Genel olarak nezaket ve duygu kontrolü olan ve örgüt içerisinde sesini çok yükseltmeyen; uzlaşmacı ve yardımcı kişilik tipinde olanların, örgütsel muhalefet üzerine etkilerinin negatif yönde olduğunu bulurken, yeni durumlara açık, dişlanmaktan çekinmeyen; maceracı ve sorgulayan kişilikteki bireylerin örgütsel muhalefet üzerine etkilerini pozitif yönde bulmuştur.

Örgütsel demokrasi kavramı ile ele alınan diğer bir kavram örgütsel vatandaşlıktır. Geçkil (2013: 119) üniversite hastanesi çalışanları örnekleminde hazırladığı çalışmasında, çalışanların örgütsel demokrasi algı düzeyi çoğaldıkça örgütsel vatandaşlık davranışı alt boyutlarından vicdanlı olma, nezaket ve sivil erdem davranışlarının da çoğaldığı ve bu neticede örgütsel demokrasi algısının örgütsel vatandaşlık davranışlarını desteklediği sonucuna ulaşmıştır. Barutcu (2019: 59) banka çalışanları üzerine hazırladığı çalışmasında, katılımcıların, örgütsel demokrasi değişkeni alt boyutları olan; şeffaflık, adalet, eşitlik ve hesap verebilirliği algılama düzeylerinin yükseldikçe, örgütsel vatandaşlık davranışlarının da artacağ 1 sonucuna ulaşmıştır.

Kara (2020: 85) yüksek lisans çalışmasında, örgütsel demokrasinin işten ayrılma niyeti üzerine etkisini araştırmıştır. Bu doğrultuda çalışanların örgütsel demokrasi algılarının işten ayrılma niyetlerini negatif yönde etkilediği sonucuna ulaşmıştır. Çalışanların görev yaptıkları kurumlardaki demokrasi algıları arttıkça, işten ayrılma niyetlerinin azalmakta olduğu sonucuna ulaşmıştır.

Günden (2019: 95) turizm çalışanları üzerine hazırladığ1 doktora çalışmasında, katılımcıların örgütsel demokrasi algılarının, örgütsel bağlılık ve örgütsel vatandaşlık ile ilişkili olduğu sonucuna ulaşmıştır. Örgütsel demokrasi algısının varlığının, alt, orta ve üst düzey yöneticilerin görmedi yerde bile hizmet sunumunda, yüksek örgütsel bağl1lık ve örgütsel vatandaşlık algısı ile kurum açısından olumlu davranışların sergilenebileceğini ifade etmiştir.

Erkal (2012: 198) çalışmasında, kamu çalışanlarının örgütsel demokrasi algılarıyla, iş tatmin düzeyleri arasında ilişki bulurken, özel sektör çalışanlarının örgütsel demokrasi algıları ile iş tatmin düzeyleri arasında herhangi bir ilişkiye rastlamaması durumunu, kamu sektöründeki çalışanların çalışma saati, ücret vs 
gibi faktörlerinin iş tatmin düzeylerini olumlu etkilemesi nedeniyle olabileceğini ifade etmiştir.

Öğretmenler örnekleminde ele alınan çalışmalara bakıldığında: Şeker (2010: 153)'in öğretmenler örnekleminde hazırladığı yüksek lisans tezinde örgütsel demokrasi bilincinin Türk Eğitim sisteminde daha etkin var olabilmesi için; uygulanma ortamlarının artması gerektiğini vurgulamıştır. Bunun yanısıra eğitim kalitesinin artması adına tüm paydaşların dâhil olabileceği katılımlı yönetim anlayışının benimsenmesinin gerektiği, yerinden yönetim uygulamaları için gerekli zeminin oluşturulmasının, veli ve öğrencilerin de seçimle yönetimde yer alabilmelerinin önemine değinmiştir.

Tokgöz (2019) öğretmenler örnekleminde hazırladığ çalışmasında, örgütsel demokrasi değişkenin iki önemli alt boyutu olarak katılım ve şeffaflığın, eğitim kurumlarındaki yönetici ve öğretmenlerin iş stresi düzeylerini anlamlı yordamlamadığı sonucuna ulaşırken, örgütsel demokrasi değişkeninin adalet alt boyutunun, katılımcıların iş stresi düzeylerini negatif yönde yordamladı̆̆ 1 sonucuna ulaşmıştır. Yani eğitim kurumundaki yöneticilerin adaletli davranışları çoğaldıkça, çalışanların iş streslerinin de azaldığı sonucuna ulaşmıştır.

Veri tabanlarından edinilen bilgilere göre çalışmalarda, örgütsel demokrasinin bazı demografik değişkenlere göre ne şekilde farklılaştığına ilişkin neden sonuç ilişkileri de ele alınmıştır. Benlioğlu (2021: 92), kamu ve özel sektördeki çalı̧̧anların psikolojik güven, çalışan sesliliği ve örgütsel demokrasi algılamalarına ilişkin farklılık testlerine ait sonuçları doktora çalışmasında sunmuştur. Bu sonuçlara göre; çalışanların cinsiyet, medeni durum, sektör, yaş, çalışma süresi değişkenlerine göre örgütsel demokrasi algılamalarında herhangi bir farklılık olmadığı, sadece eğitim değişkeninde lisansüstü eğitim alanların örgütsel demokrasi ortalamalarının daha yüksek olduğu sonucuna ulaşmıştır.

Kara (2020: 45) ve Yalçınkaya (2019: 63) katılımcıların örgütsel demokrasi algılama düzeylerinde; yaş, eğitim durumu, medeni durum, sektör deneyimi gibi değişkenlerde herhangi bir farklılığa rastlamamıştırlar. Iş̧ı (2017), katılımcıların örgütsel demokrasi algılamalarında, cinsiyet, medeni durum, eğitim, gelir ve statü durumlarına göre herhangi bir farklılığa rastlamazken, yaş ve çalışma süresine göre farkl1l1k tespit etmiştir.

Yıldırım (2020: 95) beyaz yakalı çalışanlar üzerine hazırladığı doktora tezinde; örgütsel demokrasi değişkeninin katılımcıların yaş, medeni durum, çalışma süresi, eğitim durumu, problemi aktarma tercihi (yüz yüze, telefonla, e posta ile) ve yaşadıkları ile göre örgütsel demokrasi algılamalarında herhangi bir farklılık olup olmadığını araştırmıştır. Araştırma sonucunda tüm demografik değişkenlerde herhangi bir farka rastlamamıştır. Ataç (2015: 206) beyaz yakalı çalışanlar üzerine yaptığı çalışmasında, beklentisinin aksine, eğitim düzeyi lise 
olan çalışanların eğitim düzeyi daha yüksek olan çalışanlara göre örgütsel demokrasi algılamalarının yüksek olduğu sonucuna ulaşmıştır. Düşük beklentili, düşük eğitim düzeyindeki çalışanların mevcut durumdan rahatsız olmayabileceği için örgütsel demokrasi algılama ortalamalarının yüksek çıkabileceğini ifade etmiştir.

Karatepe (2019: 106) hemşireler örnekleminde yaptığı doktora çalışmasında, özel sektörde görev yapan hemşirelerin, örgütsel demokrasi algılarının genel ve alt boyutlarındaki ortalamalarının yüksek olduğu sonucuna ulaşmıştır. Bunun nedeni olarak; özel sektördeki hastanelerde hasta ve çalışan memnuniyeti odaklı çalışmanın bürokrasi basamaklarını azaltarak, örgütsel demokrasi ortamını desteklemiş olabileceğini öne sürmüştür. Erkal (2012) kamu ve özel sektör çalışanlarının örgütsel demokrasi algılama durumlarını karşılaştırmak üzere hazırladığı çalışmasında, kamu sektöründe merkezi yönetim söz konusu olduğu için çalışanların kararlara katılımın daha az olduğu ve örgütsel demokrasi algılarının düşük çıktığını ifade etmiştir.

Kesen (2015) çalışmasında, örgütsel demokrasinin çalışan performansını arttırmada önemli bir rol oynadığı, kararlara katılım, eleştiri ve problemleri dile getirme imkânı olan çalışanların kurumun eksikliklerini daha iyi bir şekilde gündeme getirip, problemlerle ilgili daha fazla olumlu çaba harcayacağını aktarmıştır.

Bakan, Güler ve Kara (2017: 1043) çalışmalarında; örgüt içerisinde çift yönlü iletişimin varlığı, çalışanlara gelişim imkânlılarının sunulması, yöneticilerin çalışanlarla önemli konularda istişare etmesi gibi şeffaflık sağlayan durumların örgüt içerisinde adalet algısını da arttırdığı sonucuna ulaşmışlardır.

$\mathrm{Bu}$ doğrultuda içerik analizi ile elde edilen bilgiler sonucunda; çalışanlara bürokrasi basamaklarının azaltılarak, örgütsel muhalefet ortamlarının sunulması ve kendi düşüncelerini rahatlıkla ifade edecekleri ortamların yaratılmasının; örgüt içerisinde farklı yenilikçi fikirlerin ortaya çıkması, sorunlara yönelik farklı çözüm yöntemlerinin gündeme gelmesi, örgüte olan bağlılı̆̆ın ve güvenin artmas1, örgütsel adalet duygusunun gelişmesi, çalışanların işten ayrılma niyetlerinin azalması, performanslarının artması açısından oldukça önemli olduğu sonucuna ulaşılmıştır. Bu alanda yapılan çalışmaların artması katılımcı yönetim anlayışına ilişkin farkındalığı da arttıracağı için literatürde konuya ilişkin daha fazla çalışmanın yapılması hususunda öneride bulunulabilir.

\section{KAYNAKÇA}


Ahmed, K., Adeel, A., Ali, R. ve Rehman, R. U. (2018). Organizational democracy and employee outcomes: the mediating role of organizational justice, Business Strategy and Development, 2 (3), 204-219.

Bakan, İ. Güler, B. ve Kara, E. (2017). Örgütsel demokrasinin örgütsel adalet ve örgütsel destek algıları üzerine etkileri: otel çalışanlarına yönelik bir araştırma, Süleyman Demirel Üniversitesi İktisadi ve İdari Bilimler Fakültesi Dergisi, 22 (4), 1031-1048.

Barutcu, H. (2019). Ö̈rgütsel demokrasinin örgütsel vatandaşlık davranışı üzerine etkisi, [Yayınlanmamış Yüksek Lisans Tezi]. Beykent Üniversitesi.

Benlioğlu, B. (2021). Psikolojik güvenin rol içi performansa etkisinde çalı̧̧an sesliliği ve örgütsel demokrasinin rolü, [Yayınlanmamış Doktora Tezi], Başkent Üniversitesi.

Bozkurt, S. (2012). Örgütsel demokrasiyi ve akademik özgürlüğ̈̈ benimseme ve Türkiye'de uygulanabilir bulma düzeyine ilişkin ögretim elemanlarının görüşleri, [Yayınlanmamış Yüksek Lisans Tezi], Ankara Üniversitesi.

Can Üst, Ç. (2020). Örgütsel demokrasi boyutlarının incelenmesine yönelik açıllayıcı bir karma yöntem araştırması, [Yayınlanmamış Yüksek Lisans Tezi], Akdeniz Üniversitesi.

Çavuş, M. F. ve Biçer, M. (2021). The effects of organizational democracy on organizational citizenship behaviors, Manas Sosyal Araştırmalar Dergisi, 10 (1), 387-396.

Çilingir, A. (2017). İletişim alanında içerik analizi yöntemi kullanılarak yapılan yüksek lisans ve doktora tezleri üzerine bir inceleme, Erciyes Illetişim, 5 (1), 148-160.

Çopur, Z. ve Atanur Baskan, G. (2020). Örgütsel demokrasi ile örgütsel sinizm arasındaki ilişki: öğretim elemanları üzerine bir araştırma, Yükseköğretim Dergisi, 10 (1), 61-72.

Çoşan Erkal, P. (2012). Örgütsel demokrasi: kamu ve özel sektör çalışanlarına yönelik bir araştırma, [Yayınlanmış Doktora Tezi], Celal Bayar Üniversitesi.

Demirtaş, H. (2017). Örgütsel demokrasi bağlamında sendikal demokrasinin sendikal bağlllı̆̆a etkisi (İzmir ilinde bir inceleme), [Yayınlanmış Yüksek Lisans Tezi], Süleyman Demirel Üniversitesi. 
Erdal, İ. (2020). Öğretmen görüşlerine göre okullarda örgütsel demokrasi ve örgütsel muhalefet arasındaki ilişkinin incelenmesi, [Yayınlanmamış Yüksek Lisans Tezi], Marmara Üniversitesi.

Erkasap, A. (2020). Çalışanların kişilik özellikleri ile örgütsel demokrasi algılarının örgütsel muhalefet davranışlar ve örgütsel sessizlikleri üzerindeki etkilerinin incelenmesi, [Yayınlanmamış Doktora Tezi], İstanbul Ticaret Üniversitesi.

Geçkil, T. (2013). Örgütsel demokrasi ile örgütsel vatandaşlık davranışları arasindaki ilişki: Trb1 bölgesindeki üniversite hastanelerinde bir uygulama, [Yayınlanmamış Doktora Tezi], Cumhuriyet Üniversitesi.

Günden, Y. (2019). Otel işletmelerinde örgütsel demokrasi algısinin örgütsel vatandaşlı̆̆a etkisinde örgütsel bă̆lllı̆̆ın rolü: Kapadokya örneği, [Yayınlanmamış Doktora Tezi], Nevşehir Hacı Bektaş Veli Üniversitesi.

Harrison, J. S., ve Fieeman, H. E. (2004). Special topic: democracy in and around organizations, Academy of ManagemenI Executive, 18 (3), 4953.

Işık, M. (2017). Kamu kurumlarında örgütsel demokrasi algısı (İş-Kur Isparta il müdürlügü örneği), Süleyman Demirel Üniversitesi İktisadi ve İdari Bilimler Fakültesi Dergisi, 22, (15) Özel Sayısı, 1661-1672.

Kaplan, A. (1943). Content analysis and the theory of signs, Philosopy Science, 10 (4), 230-247.

Kara, R. (2020). Aile işletmelerinde algılanan örgütsel demokrasinin işten ayrılma niyeti üzerine etkisi, [Yayınlanmamış Yüksek Lisans Tezi], Toros Üniversitesi.

Kuşcu Karatepe, H. (2019). Hemşirelerde politik duyarlılık ve örgütsel demokrasi algısı arasındaki ilişkinin belirlenmesi, [Yayınlanmamış Doktora Tezi], İstanbul Üniversitesi.

Oral Ateş, L. (2015). Örgütsel demokrasi ve örgütsel muhalefet ilişkisi: beyaz yakalılar üzerine bir araştırma, [Yayınlanmış Doktora Tezi], Manisa Celal Bayar Üniversitesi.

Öztürk, M. ve Demirtaş, H. (2019). Örgütsel demokrasi bağlamında sendikal demokrasinin sendikal bağlılığa etkisi (İzmir ilinde bir inceleme), $\dot{I}_{s ̧} v e$ Hayat, 5 (9), 9-3. 
Sadykova, G. ve Tutar, H. (2014). Örgütsel demokrasi ve örgütsel muhalefet arasındaki ilişki üzerine bir inceleme, Işsletme Bilimi Dergisi, 2 (1), 1-16.

Safari, A. Salehzadeh, R. ve Ghaziasgar, E. (2017). Exploring the antecedents and consequences of organizational democracy, The TQM Journal, 30 8(1), 74-96.

Şeker, G. (2010). Yönetici ve ögretmen algılarına göre ilköğretim okullarında örgütsel demokrasinin benimsenme ve uygulanabilme düzeyi, [Yayınlanmış Yüksek Lisans Tezi], Yüzüncü Yıll Üniversitesi.

Tokgöz, A. (2019). Yönetici ve ögretmenlerin örgütsel demokrasi algisı ile iş stresi düzeyi arasındaki ilişkinin incelenmesi, [Yayınlanmamış Yüksek Lisans Tezi], Burdur Mehmet Akif Ersoy Üniversitesi.

Turabik, T. (2019). Yüksekögrretim örgütlerinde örgütsel demokrasi ile politik davranışlar arasındaki ilişki, [Doktora Tezi], Hacettepe Üniversitesi.

Uysal, A. (2019). Örgütsel demokrasinin örgütsel bağlllı̆ga etkisi: İstanbul deniz otobüsleri çalışanları örneği, [Yayınlanmamış Yüksek Lisans Tezi], İstanbul Gelişim Üniversitesi.

Verdorfer, A. P. ve G.Weber W. (2016). Examining the link between organizational democracy and employees' moral development, Journal of Moral Education, 45 (1), 59-73.

Yalçınkaya, K. (2019). Örgütsel demokrasinin çalışanların bağlllık duygusu üzerindeki etkisi ve analitik bir çalışma, [Yayınlanmamış Yüksek Lisans Tezi], Haliç Üniversitesi.

Yıldırım, M. (2020). Çalışanların örgütsel demokrasi algılarının örgütsel muhalefet davranışl ve işle bütünleşme düzeyine etkisi: bir alan araştırması, [Yayınlanmamış Doktora Tezi], İnönü Üniversitesi. 